\title{
Leadership, Organization and Management of Works in Enterprise
}

\author{
$\mathrm{PhD}$ (C) Ardian Berisha
}

\author{
European University of Tirana, Economics Faculty, Management department
}

\section{Doi:10.5901/ajis.2016.v5n3s1p68}

\begin{abstract}
Enterprise is professional people organization, capital union, organizational structure, internal acts for leadership and management, which is known by state institutions, has been created as per law and by license taken or work permit from respective state institution (Agency for Business Registration in Republic of Kosovo), which is functioning as agency within the Ministry of Trade and Industry of Kosovo. There are known 3 forms of enterprises: small, medium and big enterprises known as corporeity's. In today's literature, but also in daily life, there is wide treatment for the term 'enterprise', respectively small and medium businesses. However, there is no agreement for the thing that which are the criteria's that can define enterprise or business to be small or medium. However, some of the characteristics that made businesses different from each other are very visible. Pizzeria, hairdresser saloon, shop, vehicle service are small business, but factory for bus production, furniture factory, air companies are big businesses.
\end{abstract}

Keywords: Enterprise, Businesses.

\section{Introduction}

Leadership is important topic that is studied and discussed in different scientific and professional circles. This is multidisciplinary topic, and as that type, it can touch many scientific fields, starting from management cases with economic-business enterprises, and up to politic level of leadership and political government in country. Leadership known as process of influence to the dependents is very important for entrepreneurship development.

In today's language, with word "leadership" mainly we can understand the ability to lead or to run and mainly is connected with tasks or responsibility or official authority of a person. There are some definitions for leadership, that tent to set up functions, qualities and leader's mail role.

Briefly saying, leadership include actions to affect individual and group behaviors of people in work. To lead means to have influence in people so that it can realize general goals. Leadership includes mainly activities about inter-human aspects of management. Leadership as management function includes motivation, leadership styles, possible accesses and communication.

Leadership in order to have success, must employ people with high level of qualifications in management field, and to have permanent training and education program for the managerial staff by adapting it hierarchical level and professional education and training.

For enterprise leadership are known three hierarchical levels: high level - top management, medium and lower level of management and leadership. In this managerial structure, employers aren't included, but, included are all level that has to do with leadership at least small group of people.

\section{Enterprise Definition}

One of the definitions for small business has been given from the Committee for Economic Development, and according to them there must be filled two or more following characteristics:

1. Firm management is independent and usually managers in the same time are also owners,

2. Capital is under ownership of one person or small group,

3. Region of distribution usually is small, and employers and owners are from the same region. But, the market does not mean to be local,

4. Relative size of the firm in the industry framework also must be small where it can be compared with biggest enterprises in the region. This can be shown in terms as sales size, number of employers or big number of important comparisons. It is clear that during definition of small and medium business that it must be taken into 
consideration more criteria's, which can help.

As those criteria's must be considered as following:

- Business must be independent,

- Business cannot be dominant in the region where it is operating,

- Number of employers,

- Revenues from sales.

Definition of small enterprises in Great Britain, small economy is among most developed in Europe. Long time before, in comparison with other European countries, it has been understood the importance of small economical subjects. Government of Great Britain created Committee for Researching Small Economic Subjects known also as The Committee of Inquiry on Small Firms, on top of which was J. E. Bolton.

Small and medium economic subjects must fulfill at least two from three bellow written criteria's:

$\begin{array}{lcc} & \text { Small } & \text { Big } \\ \text { Turnover from sales (in million pounds) } & 2.8 & 11.2 \\ \text { Balance (in million pounds) } & 1.4 & 5.6 \\ \text { Number of employers } & 50 & 250\end{array}$

During the definition of business into consideration must be taken more criteria's which can define what is small business. But, the more general criteria for SME definition is average number of employers. Definition of small enterprises in Croatia, small economy has been made from subjects that:

- Employ on the average less than 250 employers per year,

- Are independent in their activity.

Realize total turnover of $60,000,000.00 €$ million Kuna's.

As per law for supporting small and medium enterprises Law No. 02/L-5, small enterprise can be known as

- Enterprise that employ up to 9 employers and

- That during previous 12 months had total turnover of 500,000.00€ or less.

But, a medium enterprise is enterprise that:

- Employ from 10 up to 49 employers and

- During previous 12 months had total turnover of 2,400,000.00€ or less.

But, we must notice that this law had suffered root changes with its amendment and law for changing and fulfilling the Law No. 02/L-5 for supporting small and medium enterprises Law No. 03/L-031 foresee this definition for small and medium enterprises:

Enterprise in order to get status of one of the classified enterprises must fulfill conditions as bellow:

- Micro-enterprises must employ up to 9 employers,

- Small enterprise must employ from 10 to 49 employers,

- Medium enterprise must employ from 50 to 249 employers.

\subsection{Type of enterprises in Kosovo}

As per activity type, enterprises in Kosovo can be production, trade and services enterprise.

Production enterprise are those businesses that produce products and other goods to complete consumer needs.

Trade enterprise are those businesses that deals with transaction of products and other goods,

Service enterprise are those businesses that carry services and other goods to complete consumer needs.

\subsection{Enterprises structure as per legal statute}

Law for trade companies in Republic of Kosovo Law No. 02/L-123 has foreseen this structure of enterprises in Kosovo: Trade company can be created in Kosovo as:

- Individual business,

- General partnership,

- Limited partnership,

- Limited Liability Company and,

- Joint stock company. 


\subsection{Businesses role in national companies}

In economic literature from developed states, apart there are 4 factors for the contribution of small and medium enterprises in trade economy and those factors are shown below:

- Contributions in different technological processes,

- Contribution in bringing healthy competition,

- Opening new job places,

- Rich offer of products in local market.

Here, we must add the fact that development of small enterprises contributes also in transition countries in resurrection of entrepreneurship initiative for changing economic structure and more accordions functioning of economy in general.

However, form all those contributions, the most importance has been shown to the employment in which small enterprises use very big place. In economic literature, there were made some development of a certain number of accesses for analyzing effects of flexible technology in business increase. Flexible technology has made possible some changes in production scale, in mix product during whole life circle of the product, and some other changes in design. This form of flexibility has been made possible with some advantages in information technology. Bigger flexibility in technology can be found at bigger enterprises than in small enterprises because bigger enterprises have more resources (capital).

Despite the fact that small enterprises are important source of knowledge creation (with this also of the economic development), many authors believe that small businesses are also very important source for creating new job places. By decreasing unemployment, there is indirect affect in country economic development. In this context, self-employment has attracted attention of worlds economists.

Logic connection between self-employment and economic growth is as follows: self-employment promotes inventions and innovations and by this it comes up creating new job places; new businesses increase competition scale in the market (through increasing number of actors in the market) and by increasing effects for consumers (by decreasing monopolists power); growth of self-employment affects also in welfare of the people and of the society.

In USA, small enterprises are seen as the way for realizing a great American dream, respectively for achieving great individual prosperity. Some research show that $40 \%$ of total $1 \%$ of rich Americans have realized career by creating economic subject. Also, there are many indicators that proof the importance of small economy not only in USA, but also in other developing countries.

We will present shortly some settings that has to deal with American economy.

- Actually, there are more than 23 million entrepreneurs. Less than 7,000 belong to the greater corporates (with more than 500 employers.

- Traditionally $75 \%$ of new job places are opened by creating new economic subjects, but other part of job places is created from their growth and development. In the period from 1986 to 1990, bigger corporates didn't open any new job places, meanwhile in the same time small economic subjects (with less than 20 employers) had increased employment with 170\%, respectively from 1.49 million to 4.02 million.

- It is important to notice that number of subjects under woman's ownership is increased rapidly. During the period from 1982 to 1992, their number is increased from 2,613 million to 5,889 million. Today it is estimated that they make up more than $40 \%$ of whole entrepreneurs in USA.

- Small economy employs $83 \%$ of employer's power in economy, $78 \%$ in wholesale trade and $55 \%$ in trade.

- Small economy directly or indirectly affects the life of more than 100 million Americans.

- Almost half of the national gross domestic product is initiated from small economy.

- As per definition from the department of small enterprises, something more that $98 \%$ of whole economic subjects take part in small subject's category.

- Almost $90 \%$ of small economic subjects employs more than 20 people.

Regarding the power of small economy in USA, there if proof of fact that if this sector is taken as independent, could be in third place in the world. Well, immediately after the whole economy of USA and Japan. Small economic subjects obviously have testified innovation process by leading in distribution of new products and services, many time being in the same time important supplier in specialized markets. Small economic subjects are non-formal and flexible, meanwhile contemporary technology moreover improves those characteristics.

In Great Britain, entrepreneurship wave has started by the end of 80 s of the $20^{\text {th }}$ century, respectively after some time in USA. But, the expansion of entrepreneurship and impact of small economy is nevertheless even smaller that it is 
in USA. In Great Britain operates about 3.7 million economic subjects, most of them are small. Taken in general, $95 \%$ of those enterprises have less than 10 employers. Seen in general, small and medium subjects in Great Britain employs $55 \%$ of total number of the employers and realize $50 \%$ of turnover. It is shown that economic subjects with less than 100 employers in the 80s of last century have increased total number of employers in France, Germany, Italy, Japan, Great Britain and USA. Number of job places in small economies of those countries varies, but it is lead from USA. Taken in general, small and medium subjects employs from $60 \%$ to $70 \%$ of people's potential of the OECD countries (Organization for Economic Cooperation and Development).

\section{Enterprise Leadership}

Leadership is orientation of conduct by individuals and group and have defined company objectives. Leadership as part of the management process is realized with people and among people in order to achieve desired results. Manager must understand and know people behavior and being in situation to realize communication, to motivate and to lead - direct, realizing organization objectives.

High level of leadership is highest and most important level. They are managers that got paid mostly and have responsibility in front of Board of Directors. Top managers are chosen by Board of Directors and they are responsible for implementation of board policies. They do described duties, given from other managerial structure. They take decision and they are responsible for the success or failure of the firm.

Medium hierarchical level is second managerial level of leadership. Managers from this level communicate with top management and they are responsible for implementation of the decisions taken by top management. They must know the work process that is being developed and they manage certain groups or bigger provided departments in managerial structure of enterprise. Lower level of management, can manage with small group of people and they are included directly in the working process and firm production. They must have technical knowledge about duties that are being developed in enterprise. Structural and technological changes, and other changes in economy require from the work market people that have ability and educational preparations that guarantee their enterprises success in business. Therefore, their requests are oriented toward new forms of formal and additional education, for the reason that traditional learning form doesn't secure necessary implicated skills that will please requests of entrepreneurs. All those enterprises that have success and that have advanced with their business got support in new knowledge.

Formal education or function of professional management capacities of human resources includes several stages:

$1^{\text {st }}$ stage: Managerial capacities for concrete work,

$2^{\text {nd }}$ stage: Expansion and knowledge deepening, skills and implementation of technology in work,

$3^{\text {rd }}$ stage: Career development, preparing for making advantage and for finishing complicated managerial duties.

$4^{\text {th }}$ stage: Education and schooling for changes that will happen in the future. Education for the future. Knowledge even usually is changing as result of economic development and general development. Gained knowledge from formal learning way, with passed time and by technic-technological and informatics development, got old and in that form, they cannot be implemented. That knowledge is insufficient and every enterprise must make efforts for innovation of their managerial personnel knowledge, throughout knowledge fulfilling as follows:

- Seminars with exercise from the experience,

- Workshops with chosen topics,

- Training and simulation of works and duties,

- Case studies,

- Lectures in connection with special topics,

Those forms of learning are defined as non-formal forms of learning through which in systematic way and by plan to fulfill knowledge and necessary skills for enterprises.

Seminars are prepared and must be fit to the enterprises requests, managers request or public service holder's requests for the people that usually are in whole work relationship. As per density among first are seminars for preexperience. Those seminars attract people with academic preparation (faculty) with the aim to create pre-experience from management and business studies. Seminars usually are organized for young people and they use to serve as help for their successful career in business.

Second seminars are those that are organized for the people after substantial experience. Those seminars relatively are attended by people with the past in business. In the seminars that can gain abilities from each-other based in experience that attendees have for specific field, through experience exchange.

In third place, there are consultant seminars, which can be expanded from half day up to some weeks. Those 
seminars are organized from professional people or any professional institution. Those seminars bring together people from different professions and they have in focus thematic cases.

Fourth category of seminars are seminars that are organized in house, which by nature are same with consultative seminars. Those seminars are organized from experts of management field, which have as task to educate attendees to work together organized and effectively.

External seminars have as aim development of leadership skills and to create confidence for successfully achieving results.

Aim of seminars is to:

- Improve quality of management in enterprise,

- Improve production effects in enterprise,

- Educate attendees to decrease production and services costs and

- Educate attendees from management, marketing, finance, privatization, entrepreneurship, personnel field.

Aim of seminars is to hold desired level of personnel knowledge and enterprise managers, different institutions, in accordance with actual requests.

Enterprises in many places in the world do organize seminars with the ail to collect knowledge in one place, to develop creation abilities, by securing new quality with they want to use. Through seminars must be promoted attendees ambitions to fulfill their knowledge for the cases which they have learned in high school or university, for production, services, sales, finance and trends of fulfilling managerial knowledge which require additional education. For this reason, the way of permanent learning through seminars without disconnection from work and it is very acceptable. Seminars are one of the most effective forms, they get forced and innovated. Schooling system, high or university, even it is too much perfect in the way of applying most contemporary programs, cannot offer sufficient knowledge for concrete actual business cases, especially in places which are in transition period, as it is Kosovo.

Training - there has passed time when formal education was main source of knowledge, time has passed when managers most of the time spent in planning, organizing and control. Key and holder of quality changes, manager, in report with himself, enterprise, vicinity - take new role by investing his time in building his team, his personnel, by training it and setting up healthy relationship between its members.

Learning, training and preparation as activity has as aim to develop experience and other creative behaviors of the employers, in order to realize finishing duties in successful way. Role of training has been seen in different ways. For the employer, it is seen by adding experience in work, but at manager in adding managerial experience or better to say managers got prepared to exercise their actions, and employers got trained for work. Request for adding experience and new knowledge creation in work is permanent request for employers in dynamic society. All the employers do not have same knowledge and experience then it is shown as elementary experience for training and learning. Knowing work methods, procedures and practices which can come out from the dynamic of work are in the same time basic objectives for attending changes than come even from organization system or environment.

Dynamic and creation of new technology with add the need for employers to be trained and learned. This should be considered also for old employers in work, also to the young employers that just have started their activity in different works.

Creation conditions for motivation increase, for new achievements in work, strengthening and stimulation specific results, and support for success in specific duties are some of the requests that are made with the aim to add experience and knowledge in comparison with time.

Methods, that are mostly used today in training and learning field for the employers are:

- Exercises during the work and,

- Practice exercises,

The first one are realized during the work process and mainly in the organizational level from the employer, supervisor or instructor, and practice exercises can be developed even in organizational level even outside of it and also that if other employers with more experience or from experts.

In enterprises that have little or more of tradition, professional consultants - people that have abilities and necessary knowledge for the implementation of the training are responsible for personnel training. But, as per transferring practice knowledge, more efficient are managers. Experience and their practice abilities, knowing their enterprise, network of business connections, personally knowing human resources of his organization, made him more qualified than professional person, responsible for human resources. Human resources training in enterprise is combined with respective changes in stance, self-respect of human resources and enterprise is increased, feeling about enterprise and their ability Is increased. As well, throughout the training, experience exchange is secured and as well as knowledge of 
attendees and increase of professional level, in this way by increase organizational culture level. Human resources training is one among best non-material investments. Through human resources gaps are fulfilled during regular education, by fulfilling them for their maximal use in enterprise or anywhere else. Meanwhile, the position of one person in enterprise, institution, society more and more depends from his abilities in order to innovate knowledge's that he have, because that every day there is strong convergence between education and business. Successful enterprises through training can clarify their vision to the employers. Supporting and developing that vision, employers must have enough knowledge for sure that is might change in comparison with the knowledge gained in formal education, knowledge that got fulfilled during non-formal education, training. For this reason:

- All employers must be treated as human's in their career. Also in those work places that aren't attractive, which have usual fluctuation, there training is needed which must be in contexts of career building with the aim to be more attractive, respectively to have clear stance that all employed people request to be developed.

- Successful enterprises oblige their employers, despite their desire, to be in trainings, expanding their knowledge. This is uninterrupted learning and specialization for employers.

\section{Conclusions}

Leadership is defined as complex process during which one person can influence others to achieve mission, task or objective, by using their qualities (truth, values, character, knowledge and abilities. In this way, according to this definition, we can take out some characteristics of leadership: it is complex process, a person can influence the others to achieve pre-set aim, person value - leader to use in function for aims realization.

While "management is process of planning and taken decisions, organization, leadership and control of human, material, financial and informative resources in enterprise with the aim to achieve its ail in the most efficient and effective way". According to this definition, management consists of some characteristics from which we can notice: its process, consisted from planning, organizing, leadership and control of work of the employers (human resources), material and monetary, as well as information resources, in different organizations.

Leader has specific features to realize aims and other organizational objectives as: skills, knowledge, experience, creativity and charismas. Those features are features that leader has won with his developed experience and knowledge and are important for successful management of the organization.

Honesty, ability to delegate, inter-personal communication, humor feeling, mutual truth, common commitment, positive attitude to the group, creativity, intuition and the ability to motivate the group. Those features are identified as main features of leadership.

\section{References}

Havolli, Y (2005), Human Resource Management, University of Pristina, Faculty of Economics,

Havolli $Y$, cited work.

Horvat, D, Hovacic, M, (2008), management in small businesses, Pristina.

Law for supporting small and medium enterprises, Law No. 02/L-5, act 4, point 2 and 3.

Law for changing and fulfilling the Law 02/L-5 for supporting small and medium enterprises Law No. 03/L-031, act 3.

Mustafa, M, Kutllovci, E, Gashi, P, Krasniqi, B (2006), Small Business and Secondary Pristina.

Ramosaj, B (2004), Fundamentals of Management, University of Pristina, Faculty of Economics, Pristina. 